\title{
Monitoring the fate of dietary proteins in rumen fluid using gel electrophoresis
}

\author{
BY D. SPENCER, T. J. V. HIGGINS, M. FREER, H. DOVE \\ AND J. B. COOMBE \\ Division of Plant Industry, Commonwealth Scientific and Industrial Research \\ Organization, GPO Box 1600, Canberra, Australia
}

(Received 21 October 1987 - Accepted 25 March 1988)

1. When fractionated by sodium dodecylsulphate--polyacrylamide gel electrophoresis (SDS-PAGE), strained rumen fluid from sheep fed on pelleted lucerne (Medicago sativa) hay showed no major protein components that stain with Coomassie Blue. This feature made it possible to monitor the fate of individual polypeptides within a protein mixture incubated in rumen fluid in vitro.

2. Extracts from a number of seed meals (sunflower (Helianthus annuus), lupin (Lupinus angustifolius), rape (Brassica napus) and pea (Pisum sativum L.)), as well as casein and bovine serum albumin, were examined in this system. The protein components of each seed type showed a wide range of resistances to degradation. One protein in pea seeds (pea albumin 1), which is particularly rich in cysteine, was almost as resistant to rumen degradation as bovine serum albumin.

3. Analysis of synthetic-fibre-bag experiments by SDS-PAGE showed that the rate of loss of total protein from solid meal residues does not provide an index of the resistance of individual protein components of the meal to rumen degradation. While there was no qualitative change in the protein profile of residual pea-seed meal inside a synthetic-fibre bag, there was considerable variation in the rate at which individual, solubilized protein components were degraded in the surrounding rumen fluid.

It is well established that with most ruminant diets a major proportion of ingested protein is degraded in the rumen and a variable proportion of the released dietary nitrogen is either converted into microbial protein or excreted in the urine as urea. It is also well recognized that different proteins vary considerably in their rate of breakdown in the rumen. For example, bovine serum albumin (BSA), ovalbumin and bovine submaxillary mucoprotein are relatively resistant to rumen degradation, while casein is rapidly degraded (Annison, 1956; Mangan, 1972; Nugent \& Mangan, 1981 ; Nugent et al. 1983). As part of a study to seek out plant proteins which are naturally resistant to rumen breakdown, we are interested in extending these observations to study the relative resistance of individual proteins in a mixture of proteins such as are found in seed meals. The longer-term aim of this work is to isolate genes for rumen-resistant proteins with desirable nutritional properties, such as high sulphur-amino acid content, and to transfer these genes into forage plants. The albumin fraction of pea (Pisum sativum L.) meal is particularly rich in S-containing amino acids. The two major components of this fraction, pea albumins 1 and 2 (PA1 and PA2) account for over half the cysteine and methionine in the seed (Schroeder, 1984). If these two albumins proved resistant to degradation in the rumen, they could contribute significantly to increased wool growth.

The fate of individual proteins incubated in rumen fluid both in vivo and in vitro has commonly been followed by quantitative measurement of such components as protein- $\mathrm{N}$, peptide- $\mathrm{N}$, microbial- $\mathrm{N}$, amino acids and ammonia. More recently, Nugent et al. (1983) have demonstrated that such incubation mixtures can be successfully analysed by sodium dodecylsulphate-polyacrylamide gel electrophoresis (SDS-PAGE). We have extended this latter approach to follow the breakdown of individual polypeptide components of complex dietary sources such as seed meals, and also to gain an insight into the pattern of loss of individual protein components from a range of seed meals during their incubation in synthetic-fibre bags immersed in rumen fluid. 


\section{METHODS \\ Preparation of rumen fluid}

Two sheep (Border Leicester $\times$ Merino adult male castrate) were maintained on a diet of pelleted lucerne (Medicago sativa L.) hay for at least 2 weeks before the experiment. Each sheep had been prepared, 3 years earlier, with a rumen fistula by the procedure of Dougherty (1955) under general anaesthesia, using halothane, and fitted with a rubber cannula. Rumen fluid was collected after overnight fasting, quickly strained through muslin and diluted with 4 vol. McDougall's (1948) artificial saliva. During these manipulations, the rumen fluid and the buffer solution were maintained at $39^{\circ}$ in an atmosphere of carbon dioxide.

\section{Extraction of seed meals}

Sunflower (Helianthus annuus cv. Hysun 30) seeds were first dehulled; other seeds (rape (Brassica napus cv. Oro), lupin (Lupinus angustifolius cv. Illyarrie), pea (cv. Greenfeast)) were ground directly in a mortar. The sunflower- and rape-seed meals were first extracted by further grinding with hexane. The hexane was discarded and the residue air-dried. The ground meal of all four species was extracted by grinding in a mortar with $4 \mathrm{vol} .(\mathrm{w} / \mathrm{v})$ of a solution containing $0.5 \mathrm{M}$-sodium chloride and $0.02 \mathrm{M}$-N-Tris (hydroxymethyl)-methyl-2aminoethane sulphonic acid, $\mathrm{pH} 7 \cdot 8$. The total slurry was mixed thoroughly at intervals during $30 \mathrm{~min}$ and then centrifuged at $10000 \mathrm{~g}$ for $10 \mathrm{~min}$. The supernatant fraction was withdrawn and used as the total seed-protein extract. The protein content of the seed extracts was measured by the method of Lowry et al. (1951) using BSA as the standard. The average protein content of these seed extracts was $30-40 \mathrm{mg} / \mathrm{ml}$. Pea-seed albumins were prepared as described by Schroeder (1982) and the lyophilized powder was dissolved in water to give a concentration of $25 \mathrm{mg} / \mathrm{ml}$.

\section{In vitro and in situ incubation with rumen fluid}

For the in vitro experiments, $50 \mathrm{ml}$ rumen fluid, prepared as described previously, were transferred to a test-tube which was then flushed with $\mathrm{CO}_{2}$ and stoppered with a bunsen valve. To this was added a seed extract containing $75 \mathrm{mg}$ protein, then a zero-time sample $(0.5 \mathrm{ml})$ was taken, the tube re-flushed with $\mathrm{CO}_{2}$ and incubation carried out at $39^{\circ}$. Further samples were removed at intervals up to $24 \mathrm{~h}$. Samples were placed in ice immediately and frozen as soon as possible.

In situ incubation of pea-seed meal in Dacron bags in the rumen of fistulated sheep was as described by Coombe (1985). In in vitro bag experiments using unextracted seed meals, the meal $(300 \mathrm{mg})$ was sealed in a $30 \times 40 \mathrm{~mm}$ bag made from nylon cloth with mean aperture of $25 \mu \mathrm{m}$. Each bag was weighted at one end and immersed in a jar containing $50 \mathrm{ml}$ diluted rumen fluid and fitted with a bunsen valve. The jars were mounted on an oscillating frame in a water-bath maintained at $39^{\circ}$. At each time-point, a jar was removed from the water-bath, the rumen fluid collected and the nylon bag and contents rinsed three times in ice-cold water before oven-drying to constant weight at $60^{\circ}$. The residual meal was ground to a fine powder and a portion taken for total $\mathrm{N}$ determination by a Kjeldahl method (White et al. 1948). Further portions of the meal residue (12 mg) were suspended in SDS-PAGE sample buffer $(750 \mu 1)$ containing $0.125 \mathrm{M}$-Tris-hydrochloric acid, pH 6.7, and (g/l) SDS (specially pure for biochemical work; BDH) 20 , glycerol 100, bromphenol blue 0.03 , mercaptoethanol 50 . The suspension was mixed vigorously at intervals during $30 \mathrm{~min}$, heated for $3 \mathrm{~min}$ at $90^{\circ}$, centrifuged for $1 \mathrm{~min}$ at $10000 \mathrm{~g}$ and then $30 \mu \mathrm{l}$ of the supernatant solution were fractionated by SDS-PAGE. Rumen fluid samples were first centrifuged at $10000 \mathrm{~g}$ for $1 \mathrm{~min}$ to remove particulate material. Samples $(200 \mu 1)$ were then precipitated with $800 \mu \mathrm{l}$ cold acetone and allowed to stand for $30 \mathrm{~min}$ at $0^{\circ}$. The protein was 
then collected by centrifugation, the aqueous acetone was discarded and the residue dried in a gentle stream of $\mathrm{N}_{2}$. The dry residue was dissolved in $50 \mu \mathrm{l}$ SDS-PAGE sample buffer and heated for $3 \mathrm{~min}$ at $90^{\circ}$ before loading on the gel.

Rumen-fluid and seed-protein samples, prepared as described in the preceding section, were fractionated by SDS-PAGE using a modification of the Laemmli \& Favre (1973) procedure as described by Spencer et al. $(1980)$. The gels $(1.5 \times 160 \times 180 \mathrm{~mm})$ consisted of a stacking gel $(62.5 \mathrm{~mm}-\mathrm{Tris}-\mathrm{HCl}, \mathrm{pH} 6.7$, plus $(\mathrm{g} / \mathrm{l}): 60$ acrylamide, 0.8 bisacrylamide, 1 SDS, 1 ammonium persulphate, 1 tetramethyl-ethylenediamine) approximately $12 \mathrm{~mm}$ high, layered over a separating gel which contained a gradient (12.5-25\%) of acrylamide-bisacrylamide $(75: 1, \mathrm{w} / \mathrm{w})$. The separating gel contained $0.375 \mathrm{M}$-Tris- $\mathrm{HCl}$, $\mathrm{pH} 8 \cdot 4$, and $1 \mathrm{~g} \mathrm{SDS} / 1$ and was polymerized with ammonium persulphate and tetramethylethylenediamine. The separating gel solutions were not degassed before forming the gradient. Electrophoresis was carried out for approximately $16 \mathrm{~h}$ at $17 \mathrm{~mA}$, after which the gels were washed in acetic acid-ethanol $(7: 25, \mathrm{v} / \mathrm{v})$ for $1 \mathrm{~h}$, stained with Coomassie Brilliant Blue R $(5 \mathrm{~g} / 1$ ethanol-acetic acid $(40: 25 \mathrm{v} / \mathrm{v}))$ for $1 \mathrm{~h}$ to detect protein bands and de-stained in acetic acid-ethanol $(7: 25, \mathrm{v} / \mathrm{v})$.

\section{RESULTS}

When strained rumen fluid from sheep fed on lucerne hay was fractionated by SDS-PAGE, no major distinctive polypeptide components were detected by Coomassie Blue staining. The proteins contained in rumen fluid are sufficiently heterogeneous to contribute only a faint background of stainable material when resolved by gel electrophoresis (Plate $1(a)$ ). Against this background, proteins such as those extracted from sunflower meal, which have been added to rumen fluid, can be readily detected (Plate 1(a)).

These observations provided the basis for an in vitro assay system for studying the relative rate of breakdown of individual proteins in rumen fluid similar to that described by Nugent $e t$ al. (1983). Proteins can be studied either singly or in any mixture of proteins that are separable by SDS-PAGE. For example, when extracts of lupin, rape and pea seeds were separately incubated in vitro in strained rumen fluid, the major protein components of each of these seed extracts were readily detected in the zero-time sample (Plate $1(b, c$, $d)$ ). For each seed species there was a characteristic pattern of breakdown of the major protein components with a wide range of susceptibilities to degradation. There were proteins which showed some degradation in the short time taken to collect a zero-time sample, whereas others remained intact to some degree for up to $8 \mathrm{~h}$. In the case of peameal extract, there was a rapid breakdown of major subunits of pea convicilin (relative molecular weight $\left.\left(M_{\mathrm{r}}\right) 75000\right)$ and vicilin $\left(M_{\mathrm{r}} 50000\right.$ and 30000$)$ as well as the acidic polypeptide from legumin $\left(M_{\mathrm{r}} 40000\right)$. The more resistant proteins in pea seed included the albumins of $M_{\mathrm{r}} 96000,26000,6000$ and 4000 , as well as the basic subunit of legumin $\left(M_{\mathrm{r}}\right.$ 20000). In rapeseed meal (Plate $1(c)$ ), most of the subunits of both cruciferin $\left(M_{\mathrm{r}} 20000-30000\right)$ and napin $\left(M_{\mathrm{r}} 9000\right.$ and 4000$)$ were relatively resistant, although one component in the unincubated total seed extract $\left(M_{\mathrm{r}}\right.$ approximately 20000$)$ was not detected in the zero-time sample. The proteins of lupin meal gave a highly complex pattern with considerable variation in the rate of breakdown of individual components (Plate $1(d)$ ). For example, components with $M_{\mathrm{r}}$ approximately 20000 and 35000 degraded rapidly, whereas those of $30000,17000,11000$ and 4000 were far more stable.

Earlier studies (Annison, 1956; Mangan, 1972) showed that ovalbumin and BSA are relatively resistant to rumen degradation in vivo, whereas casein is rapidly degraded. In order to relate these findings to our in vitro assay, the stability of BSA and casein was monitored by the electrophoresis of samples removed at intervals during incubation of 
these proteins in sheep rumen fluid (Plate 2). Consistent with earlier results (Annison, 1956; Nugent et al. 1983), there was a marked contrast in the stability of casein and BSA in the in vitro assay. Casein was not detectable after $1 \mathrm{~h}$ of incubation, whereas some undegraded BSA remained after $8 \mathrm{~h}$.

In a total pea-meal sample (Plate $1(b))$, both PA1 $\left(M_{\mathrm{r}} 6000\right.$ and 4000$)$ and PA2 $\left(M_{\mathrm{r}}\right.$ $26000)$ appeared relatively resistant to breakdown. However, one problem that arises when using SDS-PAGE to monitor the stability of small proteins in a mixture of proteins is the possibility that polypeptides arising from the degradation of larger proteins will fortuitously co-migrate with the small protein of interest and give the latter the appearance of stability. To resolve this uncertainty, preparations enriched with the two major pea albumins were incubated in rumen fluid in vitro and their stability checked by sampling at intervals (Plate 2). Both PA1 and PA2 proved to be almost as resistant as BSA to degradation by rumen fluid.

The SDS-PAGE assay of rumen fluid with added proteins provided an opportunity to extend the many observations that have been made on the breakdown of dietary protein using the in situ bag technique (e.g. Freer \& Dove, 1984; Coombe, 1985). In a preliminary experiment, the residues of pea meal which had been suspended in Dacron bags in a sheep's rumen for varying time periods were analysed for total $\mathrm{N}$ and also fractionated by SDS-PAGE. These analyses showed (Plate 3) that the same profile of pea polypeptides was present from zero time through to $9 \mathrm{~h}$ of incubation, by which time $85 \%$ of the total $\mathrm{N}$ had been lost from the bags. After $24 \mathrm{~h}$ incubation $93.5 \%$ of the $\mathrm{N}$ had been lost and traces of the major polypeptides were still detectable. It should be noted that those polypeptides which are particularly susceptible to degradation, such as the $M_{\mathrm{r}} 75000$ of convicilin, $M_{\mathrm{r}} 50000$ and 30000 of vicilin and $M_{\mathrm{r}} 40000$ of legumin, were not preferentially lost from the pea meal.

These observations were extended in a further experiment in which small nylon bags containing pea meal were incubated in vitro in rumen fluid with shaking under $\mathrm{CO}_{2}$ and at $39^{\circ}$. At each time-point, a bag was removed and the rumen fluid in which it had bathed was also sampled. Two series of incubations were run. One used rumen fluid collected directly from the sheep, the other used a sample of the same rumen fluid which had been autoclaved for $20 \mathrm{~min}$ to kill all micro-organisms and inactivate all enzymes (Plate 4). The major contrast between the autoclaved and non-autoclaved series was in the composition of the surrounding rumen fluid (Plate $4(a, c)$ ). Once released from the bag, all the pea-meal proteins remained stable in the autoclaved rumen fluid for up to $24 \mathrm{~h}$. In contrast, in the nonautoclaved series, the spectrum of pea proteins in the surrounding rumen fluid was quite incomplete (Plate $4(a)$ ). This reflected the preferential breakdown of many of the protein components (e.g. $M_{\mathrm{r}} 75000$ and 50000) seen earlier with pea-meal extract (Plate $1(b)$ ) and the relative stability of others such as the albumins with $M_{\mathrm{r}}$ approximately 26000 and 6000 .

Analysis of the bag contents in this in vitro experiment confirmed the results seen earlier in situ. In the non-autoclaved series, the polypeptide composition of the residual pea meal remained unchanged after $8 \mathrm{~h}$ (Plate $4(b)$ ), with no indication of preferential loss of particular components. At this stage, $59 \%$ of the total $\mathrm{N}$ had been lost from the bag. Incubation of pea meal with autoclaved rumen fluid resulted in a slower loss of $\mathrm{N}$, particularly between 8 and $24 \mathrm{~h}$, with the unchanged complement of major pea-meal proteins still represented in the residue after $24 \mathrm{~h}$ (Plate $4(d)$ ). 


\section{DISCUSSION}

The fate of dietary proteins in the rumen can be measured directly in animals prepared with fistulas in the rumen and the abomasum, or duodenum (e.g. Lindsay \& Hogan, 1972; Mathers \& Miller, 1981), but the procedure is laborious and subject to error (Smith, 1975). As a result, more rapid, indirect methods have been sought for assessing the degradation of different proteins. The most widely used methods depend on either the solubility of the proteins in rumen fluid or mineral buffer solutions, or the disappearance of the proteins from synthetic-fibre bags suspended in the rumen.

Despite the early demonstration (Annison, 1956; Mangan, 1972) that some soluble proteins of animal origin are degraded only slowly in the rumen, the solubility of a protein has, until recently, had wide acceptance as an index of degradability (Wohlt et al. 1973; Crooker et al. 1978). Following from this, it has generally been assumed that proteins which disappear from a feed incubated in the rumen in a synthetic-fibre bag have been completely degraded (e.g. Ganev et al. 1979).

However, Mahadevan et al. (1980) found that soluble and insoluble proteins in soyabean meal, when incubated with protease from the rumen micro-organism Bacteroides amylophilus, were degraded at the same rate. Stern \& Satter (1984) compared solubility in a solution of Burrough's mineral buffer $(100 \mathrm{~g} / 1)$ with in vivo measurements of protein degradation in the rumen and obtained a correlation coefficient of only 0.26 .

As reported earlier (Nugent \& Mangan, 1981; Nugent et al. 1983), the SDS-PAGE procedure makes it possible to extend these observations in a more direct way by studying the degradation of individual proteins within a mixture of proteins during their incubation in rumen fluid. This application of SDS-PAGE was made possible by the finding that the proteins of the rumen microflora are extremely heterogeneous and therefore do not interfere with the detection of a limited number of added proteins (e.g. Plate $1(a)$ ). The results obtained from the incubation of protein extracts in rumen fluid show a wide variation in the rate of disappearance of individual proteins of comparable solubility (Plate $1(b, c, d)$ ). On the other hand, the protein composition of seed-meal residue remaining in the synthetic-fibre bags remained qualitatively unchanged for at least $8 \mathrm{~h}$ (Plate 4). This is consistent with the observation of Ganev et al. (1979) that there was no change in the amino acid composition of the residues of a range of seed meals incubated in the rumen in bags for $9 \mathrm{~h}$. This indicates that, in both the present experiments and those of Ganev et al. (1979), the major protein components of the seed meals were all solubilized at approximately the same rate in rumen fluid.

Comparison of the protein patterns in the material leaving the bags with that of the residues clearly shows that loss from bags is not necessarily correlated with degradation of all proteins. Nevertheless, there is substantial evidence from other workers to support the view that estimates of degradability from the synthetic-fibre-bag procedure are better correlated with in vivo estimates of degradability than are those based on protein solubility (Mathers \& Miller, 1981; Stern \& Satter, 1984).

It should be noted that the absolute rate of breakdown of any given protein in the rumen may vary with the animal's diet. A change of diet from hay plus crushed oats to fresh lucerne resulted in increases of three- and nine-fold respectively, in the rate of breakdown of BSA and Fraction 1 protein in rumen fluid from sheep (Nugent et al. 1983). The animals used in the present experiments were maintained on a constant diet of pelleted lucerne hay. In addition, each set of in vitro incubations contained a series with added BSA as a check for significant variation in the proteolytic activity of each batch of rumen fluid.

Based on in vitro experiments with a protease from a rumen micro-organism, Mahadevan et al. (1980) concluded that the level of disulphide bonding within a protein was a major 
factor in determining its resistance to degradation. Resistant proteins, such as BSA, were rendered susceptible to degradation by treatments which destroyed these disulphide bonds. Because of their relatively high cysteine content, it seems likely that the relative stability of PA1 and PA2 is also due to the presence of disulphide bonds. Our current research is aimed at using genetic engineering techniques to introduce the gene for PAl (11\% cysteine; Higgins et al. 1986) into pasture species. Since wool growth in sheep is limited by the supply of S-amino acids (Reis \& Schinckel, 1963), it is hoped that ingestion of forage containing this rumen-resistant, S-rich protein will lead to increased wool growth.

\section{REFERENCES}

Annison, E. F. (1956). Biochemical Journal 64, 705-714.

Coombe, J. B. (1985). Australian Journal of Agricultural Research 36, 717-728.

Crooker, B. A., Sniffen, C. J., Hoover, W. H. \& Johnson, L. L. (1978). Journal of Dairy Science 61, 437-447.

Dougherty, R. W. (1955). Cornell Veterinarian 45, 331-357.

Freer, M. \& Dove, H. (1984). Animal Feed Science and Technology 11, 87-101.

Ganev, G., Ørskov, E. R. \& Smart, R. (1979). Journal of Agricultural Science, Cambridge 93, 651-656.

Higgins, T. J. V., Chandler, P. M., Spencer, D., Beach, L. R., Blagrove, R. J., Kortt, A. A. \& Inglis, A. S. (1986). Journal of Biological Chemistry 261, 11124-11130.

Laemmli, U. K. \& Favre, M. (1973). Journal of Molecular Biology 80, 575-599.

Lindsay, J. R. \& Hogan, J. P. (1972). Australian Journal of Agricultural Research 23, 321-330.

Lowry, O. H., Rosebrough, N. J., Farr, A. L. \& Randall, R. J. (1951). Journal of Biological Chemistry 193, $265-275$.

McDougall, E. I. (1948). Biochemical Journal 43, 99-109.

Mahadevan, S., Erfle, J. D. \& Sauer, F. D. (1980). Journal of Animal Science 50, 723-728.

Mangan, J. L. (1972). British Journal of Nutrition 27, 261-283.

Mathers, J. C. \& Miller, E. R. (1981). British Journal of Nutrition 45, 587-604.

Nugent, J. H. A., Jones, W. T., Jordan, D. J. \& Mangan, J. L. (1983). British Journal of Nutrition 50, 357-368. Nugent, J. H. A. \& Mangan, J. L. (1981). British Journal of Nutrition 46, 39-58.

Reis, P. J. \& Schinckel, P. G. (1963). Australian Journal of Biological Science 16, 218-230.

Schroeder, H. E. (1982). Journal of the Science of Food and Agriculture 33, 623-633.

Schroeder, H. E. (1984). Journal of the Science of Food and Agriculture 35, 191-198.

Smith, R. H. (1975). In Digestion and Metabolism in the Ruminant, pp. 399-415. [I. W. McDonald and A. C. I. Warner, editors]. Armidale: University of New England Publishing Unit.

Spencer, D., Higgins, T. J. V., Button, S. C. \& Davey, R. A. (1980). Plant Physiology 66, 510-515.

Stern, M. D. \& Satter, L. D. (1984). Journal of Animal Science 58, 714-724.

White, M. E. P., Thompson, F. B. \& Brice, N. (1948). Analyst 73, 146-148.

Wohlt, J. E., Sniffen, C. J. \& Hoover, W. H. (1973). Journal of Dairy Science 56, 1052-1057.

\section{EXPLANATION OF PLATES}

Plate $1(a)$. Fractionation of the proteins of rumen fluid and sunflower (Helianthus annuus cv. Hysun 30 ) meal by sodium dodecylsulphate-polyacrylamide gel electrophoresis (SDS-PAGE). R, strained rumen fluid; S, extract of sunflower meal. Rumen fluid, equivalent to approximately $500 \mu \mathrm{g}$ protein, and sunflower-meal extract, equivalent to $180 \mu \mathrm{g}$ protein, were fractionated as indicated.

The degradation of the protein components of $(b)$ pea (Pisum sativum cv. Greenfeast), (c) rape (Brassica napus cv. Oro) and (d) lupin (Lupinus angustifolius cv. Illyarrie) seeds during incubation in rumen fluid in vitro. Total soluble protein extracts of each seed type were incubated in rumen fluid at $39^{\circ}$ under carbon dioxide. Samples were removed at $0,1,2,4,8$ and $24 \mathrm{~h}$ and fractionated by SDS-PAGE. Protein components were stained with Coomassie Brilliant Blue R. TE, total soluble seed-protein extract, non-incubated. The numbers on the vertical axes indicate the approximate molecular weights $\left(\times 10^{-3}\right)$ of some of the major seed proteins.

Plate 2. Comparison of the rate of breakdown of casein, bovine serum albumin (BSA) and pea (Pisum sativum cv. Greenfeast) albumins during incubation in rumen fluid in vitro. Samples were removed at intervals and fractionated by sodium dodecylsulphate-polyacrylamide gel electrophoresis. The numbers on the vertical axis indicate the approximate molecular weights $\left(\times 10^{-3}\right)$ of the pea albumins. 
(a)

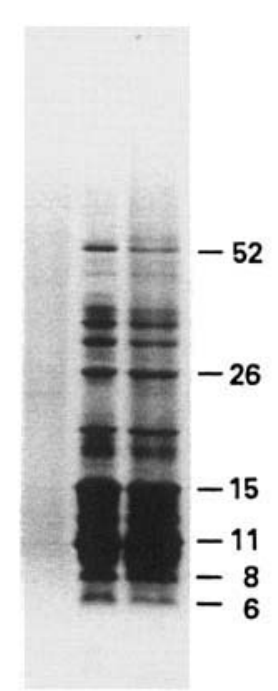

R $S R+S$

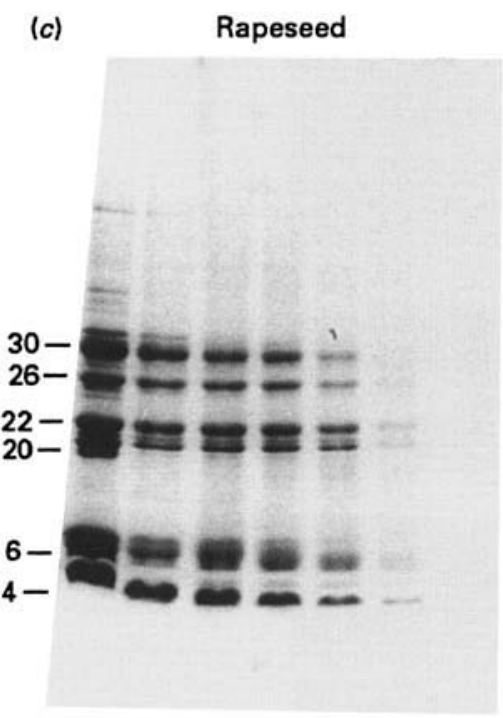

$\begin{array}{lllllll}\text { TE } & 0 & 1 & 2 & 4 & 8 & 24\end{array}$

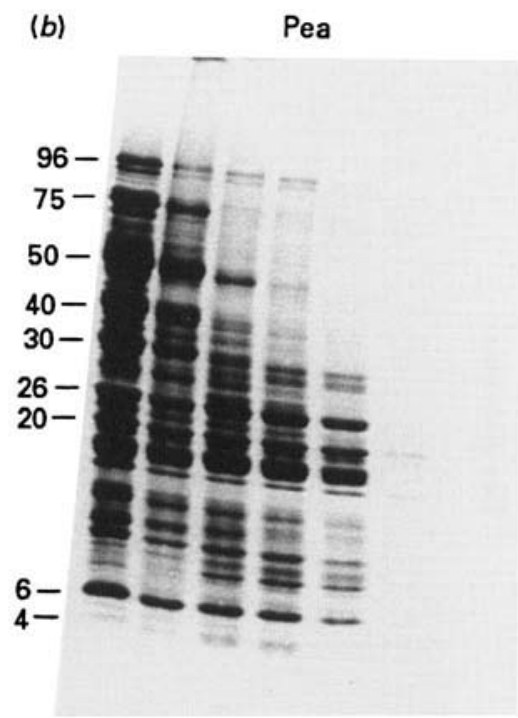

$\begin{array}{lllllll}\text { TE } & 0 & 1 & 2 & 4 & 8 & 24\end{array}$

(d) Lupin

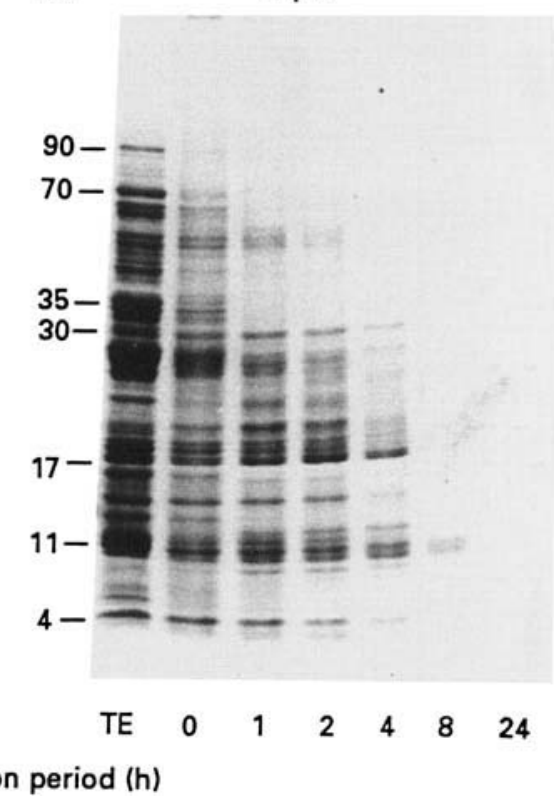




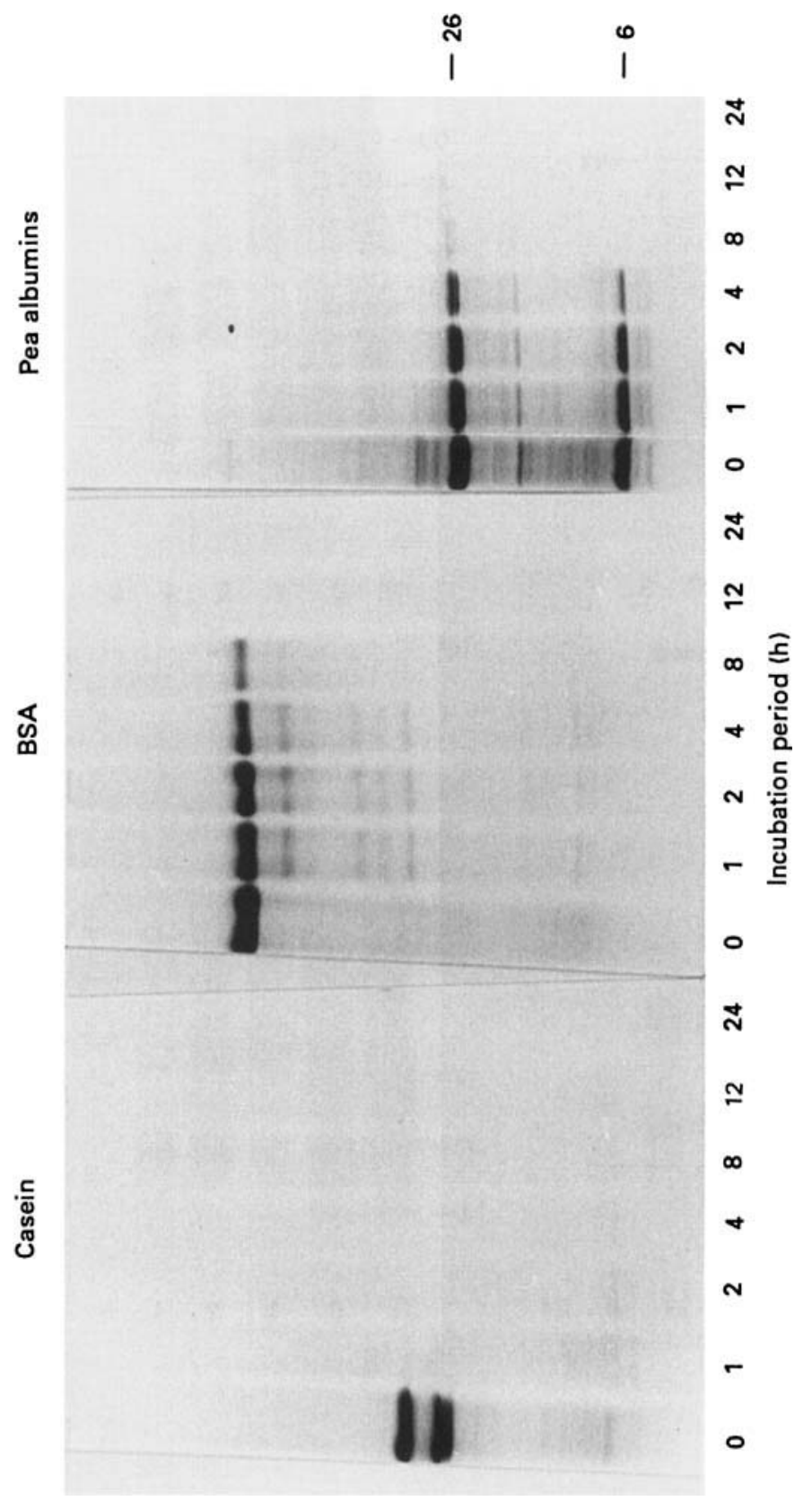


British Journal of Nutrition, Vol. 60, No. 2

Plate 3

(a)

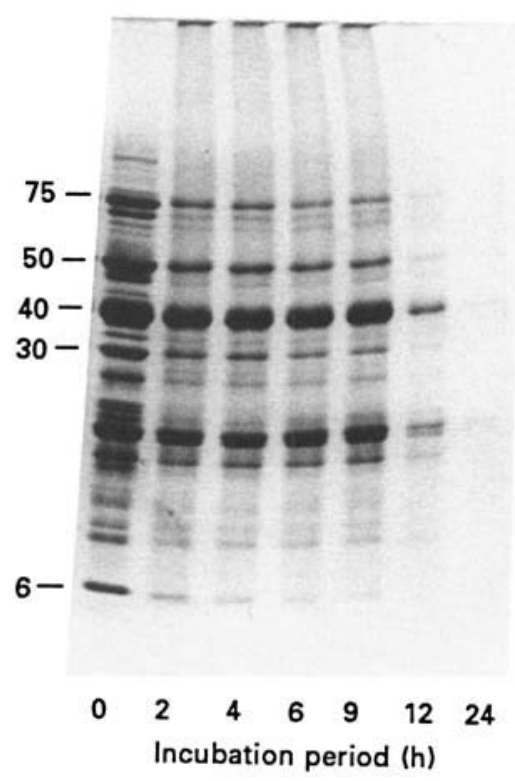

(b)

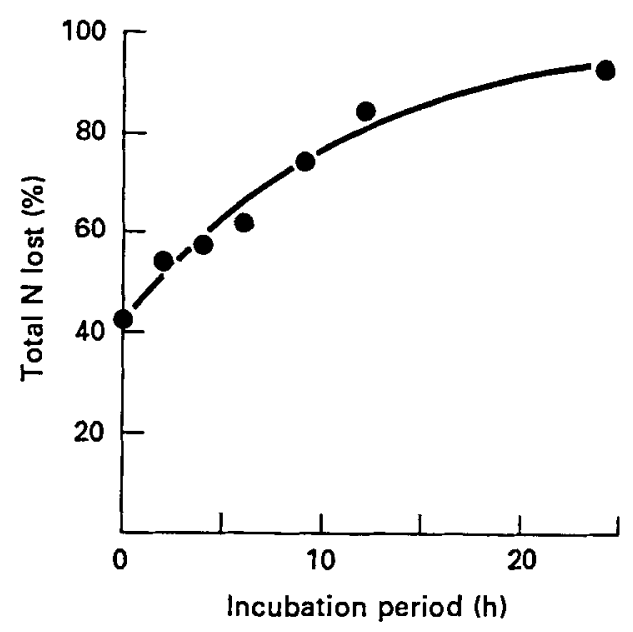


British Journal of Nutrition, Vol. 60, No. 2

Plate 4

Rumen fluid

(a)

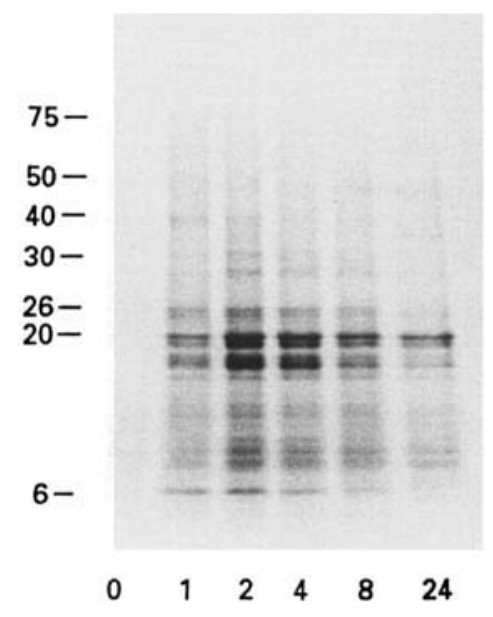

(c)

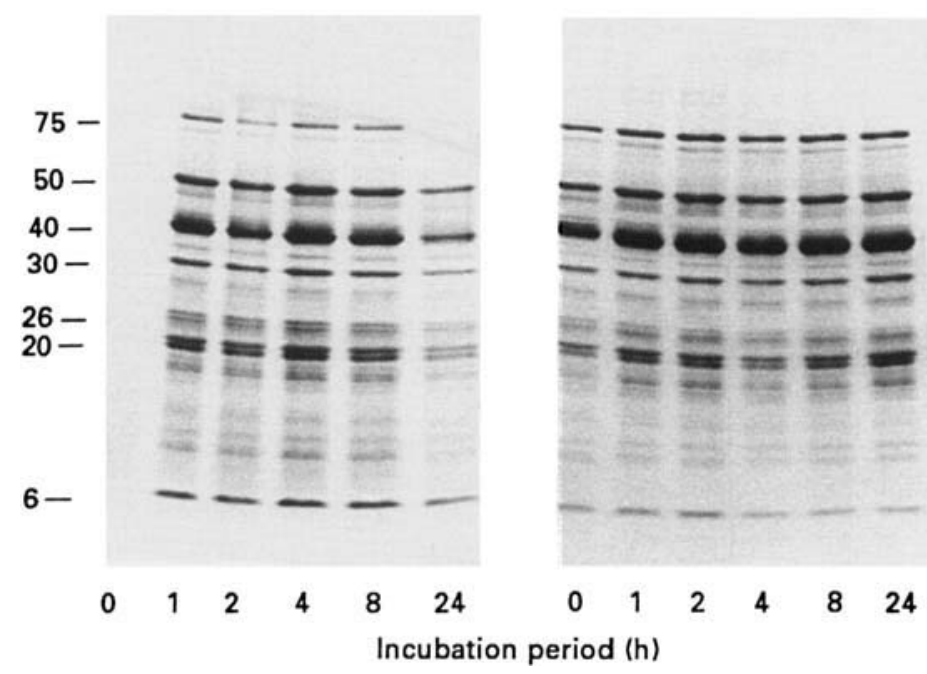

Bag residue

(b)

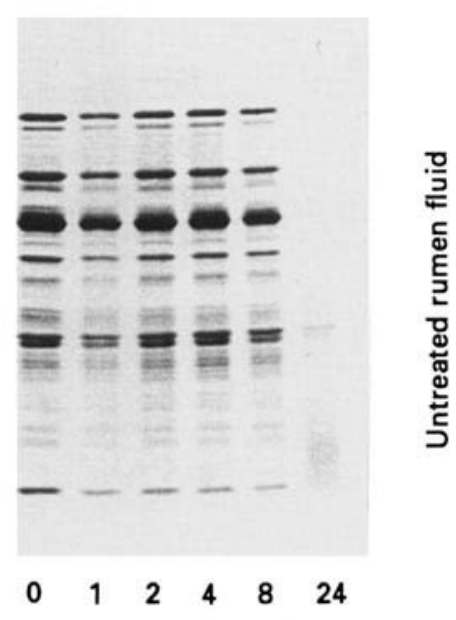

(d)

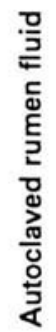


Plate 3. The protein composition of residual pea (Pisum sativum cv. Greenfeast) meal contained in Dacron bags and incubated in situ in a sheep's rumen. (a) At intervals a bag was removed, the contents dried and an equal weight of each sample was extracted and fractionated by sodium dodecylsulphate-polyacrylamide gel electrophoresis. The numbers on the vertical axis indicate the approximate molecular weights $\left(\times 10^{-3}\right)$ of pea-meal proteins. (b) Further samples were analysed for total nitrogen lost.

Plate 4. The protein composition of residual pea (Pisum sativum cv. Greenfeast) meal contained in a nylon bag $(b, d)$ and that of the rumen fluid $(a, c)$ in which it was incubated. Pea-meal samples were incubated in untreated rumen fluid $(a, b)$ or in autoclaved rumen fluid $(c, d)$. Incubations were terminated at $0,1,2,4,8$ and $24 \mathrm{~h}$ and samples of rumen fluid and extracts of residual pea meal were fractionated by sodium dodecylsulphatepolyacrylamide gel electrophoresis. The numbers on the vertical axes indicate the approximate molecular weights $\left(\times 10^{-3}\right)$ of proteins. 